\title{
Corrosion Protection of WE43 Magnesium Alloy by Fluoride Conversion Coating
}

\section{Drahomir Dvorsky, Jiri Kubasek, Dalibor Vojtech}

Faculty of chemical technology, Department of metals and corrosion engineering, University of chemistry and technology Prague, Technická 516628 Praha 6 - Dejvice, Czech Republic. E-mail: dvorskyd@vscht.cz, Jiri.Kubasek@vscht.cz, Dalibor.Vojtech@vscht.cz

\begin{abstract}
Magnesium alloys are utilized in automotive and aviation industry due to their low density and good mechanical properties. However most magnesium alloys lose mechanical properties at high temperature. Another weak point of magnesium is its high corrosion rate. Alloying by rare earth elements improves mechanical properties, corrosion resistance, and heat stability up to $300{ }^{\circ} \mathrm{C}$ by formation of intermetallic phases. Further improvement of corrosion properties can be achieved by coating. Fluoride conversion coating is ideal for magnesium alloy due to its low thickness, good adhesion and easy preparation. In this work, WE43 alloy prepared by extrusion is immersed in hydrofluoric acid to obtain fluoride coating. Extruded pure magnesium is immersed the same way as WE43 for comparison. Surface and cross section of prepared coating and corrosion properties of prepared materials are characterized. Fluoride conversion coating decreased corrosion rate by one order of magnitude for pure magnesium and by half in case of WE43 magnesium alloy.
\end{abstract}

Keywords: Magnesium, fluoride coating, corrosion, WE43, extrusion.

\section{Acknowledgement}

Authors wish to thank the Czech Science Foundation (project no. P108/12/G043), (project no. GA16-08963S) and specific university research (MSMT No 20-SVV/2017) for the financial support of this research.

\section{References}

[1] DVORSKÝ, D., KUBÁSEK, J., VOJTĚCH, D., VOŇAVKOVÁ, I., VESELÝ, M., ČAVOJSKÝ, M. (2017). Structure and mechanical characterization of $\mathrm{Mg}-\mathrm{Nd}-\mathrm{Zn}$ alloys prepared by different processes, IOP Conference Series: Materials Science and Engineering, 2017.

[2] VOJTĚCH, D., ČÍŽKOVÁ, H., POSPÍŠILOVÁ, I., VOLENEC, K. (2005). Struktura a vlastnosti slitin hořčíku pro medicínské aplikace. In Metal 2005, Hradec nad Moravicí, 2005.

[3] KUBÁSEK, J., VOJTĚCH, D., DVORSKÝ, D. (2016). Effect of microstructure on the mechanical properties of binary magnesium alloys containing Ga, In and Sn. Manufacturing Technology 2016, 16 (5), 971-978.

[4] DVORSKÝ, D., KUBASEK, J., VOJTECH, D., ČAVOJSKY, M. (2016). Structure and mechanical properties of WE43 prepared by powder metallurgy route. Manufacturing Technology 2016, 16 (5), 896-902.

[5] RZYCHOŃ T., A. K. (2007). Microstructure of WE43 casting magnesium alloy. Journal of achievements in materials and manufacturing engineering 2007, 21 (1).

[6] KUBÁSEK, J., DVORSKÝ, D., ČAVOJSKÝ, M., VOJTĚCH, D., BERONSKÁ, N., FOUSOVÁ, M. Superior Properties of Mg-4Y-3RE-Zr Alloy Prepared by Powder Metallurgy. Journal of Materials Science \& Technology.

[7] DVORSKÝ, D., KUBASEK, J., VOJTĚCH, D., PRUSA, F., NOVA, K. (2016). Preparation of WE43 using powder metallurgy route. Manufacturing Technology 2016, 16 (4), 680-687.

[8] KUBÁSEK, J., VOJTĚCH, D., DVORSKÝ, D. (2015). The effect of thermo-mechanical processing on the structure, static mechanical properties and fatigue behaviour of pure Mg. Materiali in Tehnologije 2017, 51 (2), 289-296.

[9] SONG, G. L., ATRENS, A. (1999). Corrosion Mechanisms of Magnesium Alloys. Advanced Engineering Materials 1999,1 (1), 11-33.

[10] LIU, M., SCHMUTZ, P., UGGOWITZER, P. J., SONG, G., ATRENS, A. (2010). The influence of yttrium (Y) on the corrosion of Mg-Y binary alloys. Corrosion Science 2010, 52 (11), 3687-3701.

[11] REN, M., CAI, S., LIU, T., HUANG, K., WANG, X., ZHAO, H., NIU, S., ZHANG, R., Wu, X. (2014). Calcium phosphate glass/MgF2 double layered composite coating for improving the corrosion resistance of magnesium alloy. Journal of Alloys and Compounds 2014, 591, 34-40.

[12] YAN, T., TAN, L., ZHANG, B., YANG, K. (2014). Fluoride Conversion Coating on Biodegradable AZ31B Magnesium Alloy. Journal of Materials Science \& Technology 2014, 30 (7), 666-674. 
[13] CASANOVA, P. Y., JAIMES, K. J., PARADA, N. J., HERNÁNDEZ-BARRIOS, C. A., APARICIO, M., VIEJO, F., COY, A. E. (2013). Synthesis and evaluation of MgF 2 coatings by chemical conversion on magnesium alloys for producing biodegradable orthopedic implants of temporary use. Journal of Physics: Conference Series 2013, $466(1), 012003$.

[14] LI, J.-z., HUANG, J.-g., TIAN, Y.-w., LIU, C.-s. (2009). Corrosion action and passivation mechanism of magnesium alloy in fluoride solution. Transactions of Nonferrous Metals Society of China 2009, 19 (1), 50-54.

[15] YAN, T., TAN, L., XIONG, D., LIU, X., ZHANG, B., YANG, K. (2010). Fluoride treatment and in vitro corrosion behavior of an AZ31B magnesium alloy. Materials Science and Engineering: C 2010, 30 (5), 740-748.

[16] SUN, J. e., WANG, J., JIANG, H., CHEN, M., BI, Y., LIU, D. (2013). In vivo comparative property study of the bioactivity of coated Mg-3Zn-0.8Zr alloy. Materials Science and Engineering: C 2013, 33 (6), 3263-3272.

[17] LI, Z., SHIZHAO, S., CHEN, M., FAHLMAN, B. D., DEBAOLIU, Bi, H. In vitro and in vivo corrosion, mechanical properties and biocompatibility evaluation of $\mathrm{MgF} 2$-coated $\mathrm{Mg}-\mathrm{Zn}-\mathrm{Zr}$ alloy as cancellous screws. Materials Science and Engineering: $C$.

[18] JIANG, H., WANG, J., CHEN, M., LIU, D. (2017). Biological activity evaluation of magnesium fluoride coated Mg-Zn-Zr alloy in vivo. Materials Science and Engineering: C 2017, 75, 1068-1074.

[19] JIANG, S. T., ZHANG, J., SHUN, S. Z., CHEN, M. F. (2016). The formation of FHA coating on biodegradable $\mathrm{Mg}-\mathrm{Zn}-\mathrm{Zr}$ alloy using a two-step chemical treatment method. Applied Surface Science 2016, 388, Part A, 424430 .

[20] JO, J.-H., KANG, B.-G., SHIN, K.-S., KIM, H.-E., HAHN, B.-D., PARK, D.-S., KOH, Y.-H. (2011). Hydroxyapatite coating on magnesium with $\mathrm{MgF} 2$ interlayer for enhanced corrosion resistance and biocompatibility. Journal of Materials Science: Materials in Medicine 2011, 22 (11), 2437-2447.

[21] CHIU, K. Y., WONG, M. H., CHENG, F. T., MAN, H. C. (2007). Characterization and corrosion studies of fluoride conversion coating on degradable Mg implants. Surface and Coatings Technology 2007, 202 (3), 590598.

[22] WEBER, C. M., EIFLER, R., SEITZ, J.-M., MAIER, H. J., REIFENRATH, J., LENARZ, T., DURISIN, M. (2015). Biocompatibility of $\mathrm{MgF} 2$-coated $\mathrm{MgNd} 2$ specimens in contact with mucosa of the nasal sinus - A long term study. Acta Biomaterialia 2015, 18, 249-261.

[23] LIU, X., ZHEN, Z., LIU, J., XI, T., ZHENG, Y., GUAN, S., ZHENG, Y., CHENG, Y. (2015). Multifunctional $\mathrm{MgF}$ /Polydopamine Coating on Mg Alloy for Vascular Stent Application. Journal of Materials Science \& Technology 2015, 31 (7), 733-743.

[24] MAO, L., YUAN, G., NIU, J., ZONG, Y., DING, W. (2013). In vitro degradation behavior and biocompatibility of $\mathrm{Mg}-\mathrm{Nd}-\mathrm{Zn}-\mathrm{Zr}$ alloy by hydrofluoric acid treatment. Materials Science and Engineering: C 2013, 33 (1), 242250 .

[25] TRINIDAD, J., ARRUEBARRENA, G., MARCO, I., HURTADO, I., ARGANDOÑA, E. S. d. (2013). Effectivity of fluoride treatment on hydrogen and corrosion product generation in temporal implants for different magnesium alloys. Proceedings of the Institution of Mechanical Engineers, Part H: Journal of Engineering in Medicine 2013, 227 (12), 1301-1311. 